\title{
ULTRASOUND AND ORGANIC ACIDS IN REMOVAL OF Salmonella enterica Enteritidis AND Escherichia coli FROM PEARS SURFACES
}

\author{
Jackline Freitas Brilhante de São José*1 \\ Hiasmyne Silva de Medeiros $* * 2$ \\ Patrícia Campos Bernardes ${ }^{* * 3}$ \\ Nélio José de Andrade ${ }^{* * 2}$
}

\begin{abstract}
The aim of this study was to evaluate the effectiveness of ultrasound treatment combined with organic acids in the decontamination step for pears processing. The adhesion process by Salmonella enterica serovar Enteritidis and Escherichia coli on pears surfaces was evaluated. In addition, the efficiency of ultrasound and organic acids to remove bacteria from the pears surfaces was analyzed. The average roughness $\left(R_{a}\right)$ of the pears was $11.85 \pm$ $3.53 \mathrm{~nm}$. The processes of $S$. Enteritidis and $E$. coli adherence are thermodynamically unfavorable for surface studied $\left(\Delta G_{\text {adhesion }}>0\right)$ but good adhesion occurred. These results suggest that the adhesion observed in this experiment is a multifactorial process. The number of bacteria on pears slices was 6.65 e $7.00 \mathrm{log} C F U / \mathrm{cm}^{2}$ for $E$. coli and $S$. enterica Enteritidis, respectively. All of the treatments removed more than $0.94 \mathrm{log} \mathrm{CFU} / \mathrm{cm}^{2}$. Of the treatments evaluated, a higher removal of pathogens was observed after use of $1 \%$ lactic acid, which reduced the $E$. coli and Salmonella contamination by 1.95 and $2.55 \log \mathrm{CFU} / \mathrm{cm}^{2}$, respectively. The results showed that it is possible to replace chlorinated compounds, which are frequently used to sanitize fruits and vegetables. Ultrasound can improve bacterial reduction of acetic acid treatment. These indicates that ultrasound can contribute to microbial safety of fresh products when applied in combination with chemical compounds.
\end{abstract}

\footnotetext{
*1 Federal University of Espírito Santo, CEP 29043-910, Vitória, ES, Brazil. (jackline.jose@ufes.br)

**2 Department of Food Technology, Federal University of Viçosa, CEP 36570-000 Viçosa, MG, Brazil. (nandrade@ufv.br, hiasmyne@yahoo.com.br).

***3 Federal University of Espírito Santo (patibernardes@yahoo.com.br)
} 


\section{INTRODUCTION}

Fresh vegetables are frequently consumed in daily diets, and minimally processed fruit and vegetable consumption has increased as modern society seeks healthier lifestyles (FORGHANI and $\mathrm{OH}, 2013$ ) and this contributed to the increment of fresh vegetable production (MILLAN-SANGO et al., 2015). At the same time, the number of outbreaks caused by foodborne pathogens has also amplified because of improved consumption of fresh products (SIVAPALASINGAM, 2004). The adhesion of bacteria to plant surfaces has been a problem for food safety and has become a challenge for the food industry (UKUKU and FETT, 2002). Some characteristic surfaces of fruits and vegetables favor a stronger attachment and colonization by bacteria (BASTOS et al., 2005).

Washing with sanitizing solutions is the essential step in the production chain for fresh fruits and vegetables during which the numbers of pathogenic and spoilage microorganisms can be reduced. Chlorine compounds are usually used to sanitize these foods (ALLENDE et al., 2008, RUíZ-CRUZ et al., 2007) but have also been the focus of environmental apprehension, and some environmental groups have recommended ending of their use. The risk of water hyperchlorination, which can results in high concentrations of trihalomethanes and other byproducts, must also be considered (RICO et al., 2007; SELMA et al., 2008).

It is required finding new options to reduce pathogens and, at the same time, ensure the safety of minimally processed fruits and vegetables (Sagong et al., 2011). Currently, there has been interest in new methods to guarantee the preservation of food without the use of additives. These methods are capable of maintaining the food's nutritional value and sensory aspects with low-energy consumption, at a competitive cost, and using environment-friendly products (SÃO JOSÉ et al., 2014). Organic acids are substances GRAS (Generally Recognized as Safe) and have the ability to inactivate foodborne pathogens (AKBAS and OLMEZ, 2007). These compounds have been described as antimicrobial agents due to environmental $\mathrm{pH}$ reduction, disorder of membrane transport and/ or permeability, anion accumulation, or a reduction in internal cellular pH (PARISH et al., 2003). Another option is ultrasound application, a technology that is widely applied in different areas of science and engineering as a non-thermal method, including the food industry (GOLMOHAMADI et al., 2013). This method was adopted by the electronics industry to decontaminate surfaces, and its use has recently been suggested as an alternative sanitization step in the food industry (ADEKUNTE et al., 2010, CAO et al., 2010, SAGONG et al., 2011, SÃO JOSÉ and VANETTI, 2012; FORGHANI and $\mathrm{OH}, 2013$ ). In food processing, high-intensity ultrasound at low frequencies, from 20 to $100 \mathrm{kHz}$, is functional for inactivating microorganisms (PIYASENA et al., 2003). When applied to liquids, ultrasonic waves promote cavitation, the formation, growth and collapse of air bubbles. These bubbles generate localized mechanical and chemical energies that are capable of inactivating microorganisms (ADEKUNTE et al., 2010, GOGATE and KABADI, 2009).

The aim of this work was to evaluate how the adhesion process occurs on pears surfaces and to apply ultrasound in combination or not with organic acids to remove Escherichia coli and Salmonella enterica Enteritidis adhered to these products.

\section{MATERIAL AND METHODS}

\subsection{MEASUREMENT OF THE CONTACT ANGLE}

The contact angles between the surface and water (Milli-Q), formamide (LGC Bio, São Paulo, Brazil) and a-bromonaphthalene (Merck, São Paulo, Brazil) were determined using a DSA 100 goniometer (Kruss, Hamburg, Germany). Measurements of the contact angle of one $2.0 \mu \mathrm{L}$ drop were taken each second for $30 \mathrm{~s}$ for all liquids and surfaces.

The contact angle on the surfaces of bacteria cells was measured on a layer of vegetative 
cells using the method described by Busscher et al. (1989). First, cells were activated twice in Brain Heart Infusion $(\mathrm{BHI})$ to obtain a suspension of active cultures with approximately $1.0 \times 10^{7} \mathrm{CFU} . \mathrm{mL}^{-1}$. Later, the suspension was centrifuged at $4000 \mathrm{~g}\left(4^{\circ} \mathrm{C}\right)$ for $10 \mathrm{~min}$ and then washed three times in $0.1 \mathrm{M}$ phosphate-buffered saline (PBS). The cell mass was resuspended in the buffer and deposited on a cellulose acetate membrane filter $(0.45 \mu \mathrm{m}$ pore size and $47 \mathrm{~mm}$ diameter) by filtration using negative pressure. During the filtration, $30 \mathrm{~mL}$ of pure water (Milli-Q) was added.

To standardize the moisture content, the filters were transferred into Petri dishes containing $1 \%$ agar $(\mathrm{w} / \mathrm{v})$ and $10 \%$ glycerol $(\mathrm{v} / \mathrm{v})$. The membranes were cut into three pieces to verified the contact angle of three liquids of different polarities.

\subsection{DETERMINATION OF THE TOTAL INTERFACIAL TENSION $\left(\Gamma_{S}{ }^{\text {TOT }}\right)$}

The toral interfacial tension was determined by the sum of the apolar and polar components of the respective surfaces (Equation 1):

$$
\gamma_{l}^{\text {TOT }}(1+\cos \theta)=2 \sqrt{\gamma_{s}^{W} \gamma_{l}^{W}}+2 \sqrt{\gamma_{s}^{-} \gamma_{l}^{+}}+2 \sqrt{\gamma_{s}^{+} \gamma_{l}^{-}}
$$

where $\mathrm{V}_{1}^{\text {TOT }}$ is the total interfacial tension of the liquid; $\mathrm{Y}^{\mathrm{LW}}$ is the interfacial tension of the interactions of the Lifshitz-van der Waals forces; $\mathrm{Y}^{+}$is the interfacial tension of the electron acceptor component of the acid-base component; $\gamma^{-}$is the interfacial tension of the electron donor component of the acid-base component, $\theta$ is the contact angle, and $s$ and $/$ indicate surface and liquid, respectively (VAN OSS and GIESE, 1995).

The three components of interfacial tension of the surfaces were determined from the contact angles obtained from three liquids with different polarities, whose interfacial tensions are known, as shown in Table 1. $\alpha$-bromonaphthalene is nonpolar, water is polar and formamide present intermediate polarity.

\section{TABLE 1: COMPONENTS OF THE INTERFACIAL TENSIONS OF THE SUBSTANCES AT $25^{\circ} \mathrm{C}$.}

\section{Interfacial tension (mJ.m-2)}

\begin{tabular}{ccccc} 
Substances & $\mathbf{Y}_{\mathbf{I}}^{\text {TOT }}$ & $\mathbf{Y}_{\mathbf{l}}^{\mathrm{LW}}$ & $\mathbf{Y}_{\mathbf{l}}^{+}$ & $\mathbf{Y}_{\mathbf{i}}^{-}$ \\
\hline a-bromonaphthalene & 44.4 & 44.4 & 0.0 & 0.0 \\
Water & 72.8 & 21.8 & 25.5 & 25.5 \\
Formamide & 58.0 & 39.0 & 2.28 & 39.6 \\
\hline
\end{tabular}

The interfacial tension is the result of the sum of the two components $\left(\mathrm{Y}_{s}^{\mathrm{LW}}\right.$ and $\left.\mathrm{Y}_{s}{ }^{\mathrm{AB}}\right)$ :

$$
\begin{array}{r}
\gamma_{s}^{W}=1.1\left(1+\cos \theta_{B}\right)^{2} \\
\gamma_{s}^{B}=2 \sqrt{\gamma_{s}^{+} \gamma_{s}^{-}} \\
\gamma_{s}^{t o t}=\gamma_{s}^{W}+\gamma_{s}^{\text {B }}
\end{array}
$$


where $\mathrm{Y}_{s}{ }_{\mathrm{L}}^{\mathrm{LW}}$ is the interfacial tension of the interactions of the Lifshitz-van der Waals forces; $\Theta_{B}$ is the contact angle obtained with $\alpha$-bromonaphthalene; $\gamma_{s}^{A B}$ is the polar component of the Lewis acid-base interaction; $\gamma_{s}{ }^{+}$is the interfacial tension of the electron acceptor component of the acidbase component; $\mathrm{Y}_{\mathrm{s}}{ }^{-}$is the interfacial tension of the electron donor component of the acid-base component; and $\mathrm{Y}_{\mathrm{s}}^{\text {tot }}$ is the total interfacial tension of the surface.

\subsection{FREE ENERGY OF THE HYDROPHOBIC INTERACTION $\left(\Delta \mathrm{G}_{\mathrm{sws}}{ }^{\text {TOT }}\right)$}

The total free energy of interaction among molecules of the surface(s) immersed in water (w) was determined by the sum of the apolar and polar free energies of interaction, $\Delta \mathrm{G}_{\text {sws }}{ }^{\mathrm{LW}}$ and $\Delta \mathrm{G}_{\text {sws }}{ }^{\mathrm{AB}}$, respectively.

$$
\begin{array}{r}
\Delta G_{s w s}^{t o t}=\Delta G_{s w s}^{W}+\Delta G_{s w s}^{B} \\
\Delta G_{s w s}^{W}=-2 \cdot \sqrt{\gamma_{s}^{W}-\gamma_{w}^{W}} \\
\Delta G_{s w s}^{B}=-4\left(\sqrt{\gamma_{s}^{+} \gamma_{s}^{-}}+\sqrt{\gamma_{w}^{+} \gamma_{w}^{-}}-\sqrt{\gamma_{s}^{+} \gamma_{w}^{-}}-\sqrt{\gamma_{w}^{+} \gamma_{s}^{-}}\right)
\end{array}
$$

\subsection{DETERMINATION OF THE TOTAL FREE ENERGY OF ADHESION $\left(\Delta G_{\text {ADHESION }}\right)$}

With the values of the components of the interfacial tensions, it is possible to find out the $\Delta \mathrm{G}_{\text {adhesion }}$ between two surfaces (microbial cells (b) and food surfaces (s)):

$$
\begin{array}{r}
\gamma_{b}=\gamma_{b}^{W}+\gamma_{b}^{B} \\
\gamma_{b}^{W}=\gamma_{b}^{W}+\gamma_{s}^{W}-2 \sqrt{\gamma_{b}^{W} \gamma_{s}^{W}} \\
\gamma_{b}^{B}=2\left(\sqrt{\gamma_{b}^{+} \gamma_{b}^{-}}+\sqrt{\gamma_{s}^{+}} \gamma_{s}^{-}-\sqrt{\gamma_{b}^{+} \gamma_{s}^{-}}-\sqrt{\gamma_{b}^{-}} \gamma_{s}^{+}\right)
\end{array}
$$

When free energy is correlated to the interfacial tension, $\Delta G_{\text {adhesion }}$ can then be represented by the following:

$$
\begin{gathered}
\Delta G_{\text {adhesion }}=\Delta G_{b l s}^{W}+\Delta G_{b l s}^{B} \\
\Delta G_{b l s}^{W}=\gamma_{b}^{W}-\gamma_{b}^{W}-\gamma_{b}^{W} \\
\Delta G_{b l s}^{B}=\gamma_{b}^{B}-\gamma_{b}^{B}-\gamma_{b}^{B}
\end{gathered}
$$

where $\mathrm{Y}_{\mathrm{bs}}$ is the interfacial tension between the bacterial surfaces and the adhesion surface; $\gamma_{b l}$ is the interfacial tension between the bacterial surfaces and the liquid; and $\gamma_{s l}$ is the interfacial tension between the adhesion surfaces and the liquid.

The $\Delta \mathrm{G}_{\text {adhesion }}$ values permit the comprehension of the thermodynamics of the adhesion process: if $\Delta G_{\text {adhesion }}<0$, the process is favorable; and if $\Delta G_{\text {adhesion }}>0$, the process is unfavorable. 


\subsection{ROUGHNESS MEASUREMENTS}

The microtopographies of the surfaces were evaluated using a profilometer (XP1; Ambios Technology, Santa Cruz, CA, USA). Roughness was expressed in nanometer (nm).

\subsection{EVALUATION OF ULTRASOUND AND ORGANIC ACID TREATMENTS}

Pears (Pyrus communis L.) were acquired from local retailers in Viçosa, Minas Gerais (Brazil) and stored at $7{ }^{\circ} \mathrm{C}$ for a maximum of $24 \mathrm{~h}$ before processing. The fruits were selected for firm texture and lack of splits or cracks on the surface.

A suspension of Salmonella enterica serovar Enteritidis (ATCC 13076) and Escherichia coli (ATCC 11229) vegetative cells was utilized. From a pure culture of bacteria maintained at $-80^{\circ} \mathrm{C}$ in tubes containing Brain Heart Infusion (BHI) and glycerol (80:20, v:v), we prepared suspensions containing approximately $1.0 \times 10^{7} \mathrm{CFU} / \mathrm{mL}$ of bacteria. For use in experiments, suspensions of vegetative cells were formed in two successive subcultures in $\mathrm{BHI}$ broth by incubation at $35^{\circ} \mathrm{C}$ for 24 $\mathrm{h}$. The number of microorganisms in the suspensions was determined by plating on Hektoen agar (Himedia, Brazil) and incubating the plates at $35^{\circ} \mathrm{C}$ for $24 \mathrm{~h}$.

After being washed in tap water and dried, pears was placed on sterilized plastic bags and were intentionally contaminated with S. enterica Enteritidis and E. coli. Bacteria were inoculated separately. The pears were then placed in plastic bags containing sterile BHI broth, which was inoculated with a suspension of activated S. enterica Enteritidis and E. coli to obtain an initial suspension of approximately $1.0 \times 10^{5} \mathrm{CFU} / \mathrm{mL}$. After incubation at $25^{\circ} \mathrm{C}$ for $24 \mathrm{~h}$, slices $(1.0 \times 1.0 \mathrm{~cm})$ were aseptically cut using a scalpel, and the number of adherent cells was quantified.

After the incubation time, the slices with adherent cells were statically maintained for $1 \mathrm{~min}$ in $10 \mathrm{~mL}$ of $0.1 \%$ peptone water to remove planktonic cells. The slices were then immersed in 10 $\mathrm{mL}$ of the same solution and swirled using a vortex mixer for $1 \mathrm{~min}$ to release sessile cells. Dilutions were prepared and transferred to Petri dishes containing Hektoen agar, which were then incubated at $35^{\circ} \mathrm{C}$ for $24 \mathrm{~h}$. The results were expressed as the number of $\mathrm{CFU} / \mathrm{cm}^{2}$.

\subsection{SANITIZATION PROCEDURE}

Lactic acid (95\%; Vetec $®$, Brazil), and acetic acid (95\%; Vetec $®$, Brazil) were used in this experiment. Each solution of organic acids was prepared to obtain $1.0 \%(\mathrm{v} / \mathrm{v})$. Distilled water used to prepare the solutions was previously sterilized and kept under refrigeration

The treatments used were: $1.0 \%$ Lactic acid ;1.0\% Acetic acid; $40 \mathrm{kHz}$ ultrasound; 1.0 $\%$ Lactic acid $+40 \mathrm{kHz}$ Ultrasound; and $1.0 \%$ Acetic acid $+40 \mathrm{kHz}$ Ultrasound. The organic acids solutions were prepared at the time of use. Ultrasound equipment was cleaned with a $70 \%$ alcohol solution before each treatment.

After removal of planktonic cells, one slice were placed in contact with $10 \mathrm{~mL}$ of different sanitizers for $2 \mathrm{~min}$. In case of ultrasound treatment, were placed one slice for each $10 \mathrm{~mL}$ of water or organic acid solution and applied for $2 \mathrm{~min}$ also. Treatments were performed individually in each solution .

The slices were then immersed in $10 \mathrm{~mL}$ of neutralizing agent for $1 \mathrm{~min}$ to inactivate any residual sanitizer. This agent was prepared with $10 \mathrm{~mL}$ monobasic potassium phosphate (Isofar ${ }^{\circledR}$, Brazil), $34 \mathrm{~g}$ sodium hydroxide (Vetec, Brazil), $30 \mathrm{~mL}$ of Tween 80 and $5 \mathrm{~g}$ sodium thiosulfate pentahydrate (Isofar@, Brazil) with an adjusted pH of 7.2.

The slices were then immersed in $10 \mathrm{~mL}$ of $0.1 \%$ peptone and swirled using a vortex mixer for $1 \mathrm{~min}$ to release the survival cells. These cells were counted according to the procedure described in section 2.6. 


\subsection{EXPERIMENTAL DESIGN}

All analyses were conducted in completely randomized design with three replicates. A significance level of $5 \%$ was used for Tukey's test using the Statistical Analysis System (SAS, 2006) version 9.1.

\section{RESULTS AND DISCUSSION}

\subsection{ANALYSIS OF SURFACE HYDROPHOBICITY}

From a qualitative analysis of surface hydrophobicity (analyzing the contact angle with water) (Table 2), the surface of pears was considered hydrophobic, whereas $S$. Enteritidis and $E$. coli cells surfaces were considered hydrophilic. According to van Vogler (1998), angles less than $65^{\circ}$ indicate hydrophilic surfaces, and angles exceeding $65^{\circ}$ indicate hydrophobic surfaces.

TABLE 2 - CONTACT ANGLE WITH WATER $\left(\Theta_{\mathrm{w}}\right)$, FORMAMIDE $\left(\Theta_{\mathrm{F}}\right)$ AND A-BROMONAPHTHALENE $\left(\Theta_{B}\right)$ ON DIFFERENT SURFACES.

\begin{tabular}{cccc}
\hline & \multicolumn{3}{c}{ Contact angle $\left(^{\circ}\right)$} \\
\cline { 2 - 4 } Surfaces & $\boldsymbol{\theta}_{\mathrm{w}}$ & $\boldsymbol{\theta}_{\mathrm{F}}$ & $\boldsymbol{\theta}_{\mathrm{B}}$ \\
\hline S. Enteritidis & $15.62 \pm 2.65$ & $22.88 \pm 4.15$ & $52.84 \pm 6.40$ \\
E. coli & $17.96 \pm 4.13$ & $47.42 \pm 9.52$ & $47.19 \pm 3.61$ \\
Pears & $83.48 \pm 8.96$ & $62.11 \pm 7.47$ & $45.46 \pm 5.50$ \\
\hline
\end{tabular}

Note: Values are the mean \pm standard deviation of duplicate samples.

Surface hydrophobicity was also assessed by quantitative measurements of the free energy of interaction $\left(\Delta G_{\text {sws }}\right)$. According to van Oss and Giese (1995), when the value of $\Delta G s w s^{T O T}$ is negative, surface is considered hydrophobic, and when it is positive, surface is considered hydrophilic. Thus, $S$. Enteritidis and $E$. coli cells surfaces were considered hydrophilic, whereas pears surface was considered hydrophobic (Table 3).

TABLE 3. VALUES OF THE APOLAR ( $\left.\Delta \mathbf{G}_{\mathrm{sws}}{ }^{\mathrm{LW}}\right)$ AND POLAR $\left(\Delta \mathbf{G}_{\mathrm{sws}}{ }^{\mathrm{AB}}\right)$ COMPONENTS AND OF THE TOTAL FREE ENERGY OF INTERACTION $\left(\Delta \mathbf{G}_{\mathrm{sws}}{ }^{\text {TOT }}\right)$ OF THE DIFFERENT SURFACES.

\begin{tabular}{cccc}
\hline Surfaces & $\boldsymbol{\Delta} \mathbf{G}_{\text {sws }}{ }^{\mathrm{LW}}$ & $\boldsymbol{\Delta} \mathbf{G}_{\text {sws }}{ }^{\mathrm{AB}}$ & $\boldsymbol{\Delta} \mathbf{G}_{\text {sws }}{ }^{\mathrm{TOT}}$ \\
\hline S. Enteritidis & -0.911 & 31.717 & 30.806 \\
E. coli & -1.718 & 76.150 & 74.432 \\
Pears & -1.998 & -51.000 & -52.998 \\
\hline
\end{tabular}

Note - Table values ( $\Delta$ GswsLW, $\Delta$ GswsAB and $\Delta$ GswsTOT) are calculated using the average of the angles of contact with water, formamide and $\alpha$-bromonaphthalene. 


\subsection{FREE ENERGY OF ADHESION $\left(\Delta \mathrm{G}_{\text {ADHESION }}\right)$}

Thermodynamic theory reports that adherence is a favorable process if the free energy per area unit is negative $\left(\Delta G_{\text {adhesion }}<0\right)$, meaning that a spontaneous adhesion occurs, leading to a decrease of the free energy of the system, as determined by the second law of thermodynamics. The process of $S$. Enteritidis and $E$. coli adherence are thermodynamically unfavorable $\left(\Delta G_{\text {adhesion }}>0\right)$ (Table 4) but adhesion will occurred. This result may be due to microbiological aspects of adhesion rather than thermodynamic theory. Garret et al. (2008) mentioned that important aspects that influence microbial adhesion are cellular appendages, presence of flagella, fimbriae and pili and cell surface proteins.

TABLE 4. FREE ENERGY OF ADHESION (MJ/M²) BETWEEN THE S. ENTERITIDIS AND $E$. COLI CELLS AND THE PEARS SURFACES IMMERSED IN WATER AND THE ADHESION OF S. ENTERITIDIS AND E. COLI (LOG CFU/CM²) TO THE PEARS SURFACES.

\begin{tabular}{|c|c|c|}
\hline Bacteria /surface & $\Delta \mathbf{G}_{\text {adhesion }}$ & Adhesion $\left(\log \mathrm{CFU} / \mathrm{cm}^{2}\right)$ \\
\hline S. Enteritidis / pears & 1.0998 & 6.65 \\
\hline E. coli / pears & 3.0983 & 7.00 \\
\hline
\end{tabular}

Adherence by both bacteria was observed on the surface of pears, which can be justified by the fact that pears surface is hydrophobic $\left(\boldsymbol{\theta}_{\mathrm{w}}=83.48\right)$. Total energy of adhesion values for $E$. coli adhesion $\left(\Delta G_{\text {adhesion }}=3.0983\right)$ was greater than Salmonella $\left(\Delta G_{\text {adhesion }}=1.0998\right)$, most probable for the reason that $E$. coli was more hydrophilic $\left(\Delta \mathrm{G}_{\text {sws }}{ }^{\text {TOT }}=74.432\right)$.

According to van Oss (1995), it is well known that an aqueous environment contributes to adhesion to hydrophobic surfaces due to expulsion of water but adhesion can also occur between a hydrophobic and hydrophilic surface or between two hydrophilic surfaces.

Water-bacteria interface and water-surface interface must be replaced by an interface between the bacteria and the surface. Surface hydrophobicity collaborates to remove water (ARAÚJO et al., 2009).

The most superficial structure of fruits is constituted by a thin wax layer, responsible for protection mechanisms, mainly mind related to water loss (CASTRO et al., 2002). Studies on the subject of adhesion to vegetable surfaces are scarce. It is recognized that the secretion of mucilage, which is composed of many chemical compounds such as sugars and proteins, can helps bacteria grow on vegetable surfaces (BRANDL and AMUNDSON, 2008).

\subsection{ROUGHNESS}

The average roughness $\left(R_{a}\right)$ of the pears was $11.85 \pm 3.53 \mathrm{~nm}$. Adherence process can be facilitated by an improved contact area between the microorganisms and the surface (LIMA et al., 2013). Larger surface area for bacterial colonization can be created due to elevations and depressions on surface (KATSIKOGIANNI and MISSIRLIS, 2004) and can protect bacteria from shearing forces. The size, cell dimensions and cell cycle stage of the bacterium can facilitate the accumulations in these depressions (KATAINEN et al., 2006). In their research, Wang et al. (2009) demonstrated a positive association between $R_{a}\left(R^{2}=0.96\right)$ and adhesion of $E$. coli $0157: H 7$ on the surfaces of different fruits, with a significant $(p<0.05)$ increase in residual bacterial population observed over the entire range of surface roughness evaluated, from 0.30 to $8.41 \mu \mathrm{m}$. 


\subsection{EFFECTIVENESS OF TREATMENTS TO REMOVE PATHOGENS}

The initial contamination of pears slices was 6.65 and $7.00 \log \mathrm{CFU} / \mathrm{cm}^{2}$ for $E$. coli and $S$. enterica Enteritidis, respectively. There was no significant difference $(p>0.05)$, between different treatments applied to the surface of pear to remove $E$. coli, which indicates that these treatments were equally effective at removing this pathogen.

All the treatments removed more than $0.94 \log \mathrm{CFU} / \mathrm{cm}^{2}$. Of the treatments evaluated, a higher removal of pathogens was observed after using $1 \%$ lactic acid alone that promoted removal of E. coli and Salmonella contamination by 1.95 and $2.55 \mathrm{log} \mathrm{CFU} / \mathrm{cm}^{2}$, respectively. These results are comparable with chlorine sanitizing solution that reduces 1 to 2 logarithmic cycles in the initial count sanitized fruit (SÃO JOSÉ and VANETTI, 2012). Wang et al. (2013) found that treatment of lotus sprouts with $0.5 \%$ and $2 \%$ lactic acid reduced pathogens by 1.5 and $2.3 \log$ CFU/g, respectively.

The removal of $E$. coli and $S$. Enteritidis was greater than that observed by Sagong et al. (2011) on lettuce, using $1.0 \%$ lactic acid alone that promoted removal of $1.03 \mathrm{log}$ CFU/g of E. coli O157: $\mathrm{H} 7$ and $1.39 \mathrm{CFU} / \mathrm{g}$ of $S$. Typhimurium, respectively. Velazquez et al. (2009) used $1 \%$ lactic acid on lettuce and observed a reduction of $1.71 \mathrm{log}$ CFU/g of $E$. coli O157: $\mathrm{H} 7$. In the study of Huang and Chen (2011), $1.0 \%$ lactic acid was the most effective treatment, reducing $E$. coli O157: $\mathrm{H} 7$ on spinach by $1.9 \log$ CFU/g.

\section{TABLE 5 - DECIMAL REDUCTIONS (LOG UFC/CM²) CAUSED BY DIFFERENT SANITIZERS ON S. ENTERICA ENTERITIDIS ATCC 13076 AND E. COLI ATCC 11229 ADHERED TO THE SURFACE OF PEARS.}

\begin{tabular}{|c|c|c|}
\hline \multirow[t]{2}{*}{ Sanitizers } & \multicolumn{2}{|c|}{ Reductions levels log UFC/ $\mathrm{cm}^{2^{*}}$} \\
\hline & $\begin{array}{l}\text { S. enterica } \\
\text { Enteritidis }\end{array}$ & E.coli \\
\hline $1 \%$ Lactic Acid & $2.55^{a} \pm 0.28$ & $1.95 a \pm 0.58$ \\
\hline $1 \%$ Acetic Acid & $1.01^{b} \pm 0.24$ & $1.11 a \pm 0.29$ \\
\hline Ultrasound $40 \mathrm{kHz}$ & $0.94^{b} \pm 0.63$ & $1.51 a \pm 0.44$ \\
\hline Ultrasound $40 \mathrm{kHz}+1 \%$ Lactic Acid & $1.88^{b} \pm 0.38$ & $1.88 a \pm 0.40$ \\
\hline Ultrasound $40 \mathrm{kHz}+1 \%$ Acetic Acid & $1.57^{b} \pm 0.29$ & $1.43 a \pm 0.57$ \\
\hline
\end{tabular}

*Means \pm standard deviation indicated with same letter on the same column did not differ between themselves $(p<0.05)$.

The combination of ultrasound and acetic acid promoted greater removal of initial contamination of $S$. enterica $\left(1.57 \mathrm{log} \mathrm{UFC} / \mathrm{cm}^{2}\right)$ and $E$. coli $\left(1.43 \mathrm{log} \mathrm{UFC} / \mathrm{cm}^{2}\right)$ on pears surfaces than just the application of acetic acid that promoted reduction of 1.01 and $1.11 \log \mathrm{UFC} / \mathrm{cm}^{2}$, respectively for these bacteria. However, this difference between these treatments was not significant $(p>0,05)$.

Acetic acid is a component of vinegar that is widely used for the sanitization of vegetables. Vinegar naturally contains acetic acid, and it is commonly used to flavor and acidify vegetables for salads and is still regarded as an alternative sanitizer for inactivating pathogens (SENGÜN and 
KARAPINAR, 2005). Nastou et al. (2012) highlighted that the effectiveness of acetic acid can be limited and varies depending on the type of vegetable treated.

The combination of ultrasound and lactic acid caused a significant increased on the reduction of $S$. Enteritidis in log CFU/ $\mathrm{cm}^{2}$ for pears slices. According to Gogate and Kabadi (2009) studied ultrasound combined with chemical agents. The intense pressure gradients allowed penetration of these oxidants through the cell membrane of micro-organisms. Moreover, cavitation facilitated the disintegration of micro-organisms and thus increased the efficiency of the sanitizing chemicals. Ultrasound increased removal of acetic acid in 5.65 and $8.43 \%$ in Salmonella and E. coli adhered to pears surfaces, respectively.

\section{CONCLUSION}

The process of $S$. Enteritidis and $E$. coli adhesion are thermodynamically unfavorable but adhesion will occurred because of microbiological aspects that can be involved. Ultrasound and organic acids promoted the removal of more than $0.94 \mathrm{log} \mathrm{CFU} / \mathrm{cm}^{2}$ of $E$. coli and S. Enteritidis. However, the best result was for lactic acid. The results showed that it is possible to replace chlorinated compounds. Ultrasound can improve bacterial reduction of acetic acid treatment. These indicates that ultrasound can contribute to microbial safety of fresh products when applied in combination with chemical compounds. However, it is also necessary to evaluate the possible physico-chemical, nutritional and sensory changes that these sanitizers can cause the fruit.

\section{RESUMO}

\section{ULTRA-SOM E ÁCIDOS ORGÂNICOS NA REMOÇÃO DE Salmonella enterica Enteritidis E Escherichia coli A PARTIR DE CASCAS DE PÊRA.}

O objetivo deste estudo foi avaliar a eficiência do tratamento de ultrassom combinado com ácidos orgânicos na etapa de sanitização para as peras. O processo de adesão de Salmonella enterica sorotipo Enteritidis e Escherichia coli em superfícies peras foi avaliado. Além disso, foi analisada a eficiência do ultrassom e ácidos orgânicos para remover bactérias a partir das superfícies peras. A rugosidade média $(\mathrm{Ra})$ das peras foi $11,85 \pm 3,53 \mathrm{~nm}$. Os processos de adesão de $S$. Enteritidis e $E$. coli são termodinamicamente desfavoráveis para a superfície estudada $\left(\Delta \mathrm{G}_{\text {adesão }}\right.$ $>0$ ), mas foi verificada grande adesão. Estes resultados sugerem que a adesão observada neste experimento é um processo multifatorial. A contaminação inicial nos cupons de pêra foi de 6,65 $\pm 0,83$ e $7,00 \pm 0,33 \log$ UFC $\cdot \mathrm{cm}^{2}$ de E. coli e $S$. enterica Enteritidis, respectivamente $(p>0,05)$. Todos os tratamentos removeram mais de $0,94 \log \mathrm{UFC} / \mathrm{cm}^{2}$. Dos tratamentos avaliados, o ácido lático 1\% promoveu remoção de 1,95 e 2,55 log CFU/ $\mathrm{cm}^{2}$ de E. coli e Salmonella, respectivamente. Os resultados mostraram que é possível substituir compostos clorados, que são frequentemente utilizados para sanitizar frutas e hortaliças. O ultrassom pode contribuir para maior redução da contaminação bacteriana associado ao ácido acético. Esses resultados indicam que o ultrassom é uma tecnologia emergente e pode colaborar para a segurança microbiológica quando aplicado combinado a compostos químicos.

\section{REFERENCES}

1 ADEKUNTE, A., TIWARI, B.K., SCANNELL, A., CULLEN, P.J., \& O’DONNELL, C. Modelling of yeast inactivation in sonicated tomato juice. International Journal of Food Microbiology, v.137, n.1, p.116-120, 2010.

2 AKBAS, M. Y., \& OLMEZ, H. Effectiveness of organic acid, ozonated water andchlorine dippings on microbial reduction 
and storage quality of fresh-cut Iceberg lettuce. Journal of the Science of Food and Agriculture, v. 87, n. 14, p.26092616, 2007.

3 ALLENDE, A., SELMA, M.V., LÓPEZ-GÁLVEZ, F., \& GIL, M.I. Impact of wash water quality on sensory and microbial quality, including Escherichia coli cross-contamination, of fresh-cut escarole. Journal of Food Protection, $v$. 71 , n.12, p. $2514-2518,2008$.

4 ARAÚJO, E.A., BERNARDES, P.C. , ANDRADE, N.J., FERNANDES, P.E. ; SÁ, J.P.N . Gibbs free energy of adhesion of Bacillus cereus isolated from dairy plants on different food processing surfaces evaluated by the hydrophobicity. International Journal of Food Science \& Technology, v. 44, n.1, p.2519-2525, 2009.

5 BASTOS, M.S.R., SOARES, N.F.F., ANDRADE, N.J., ARRUDA, A.C., ALVES, R.E. The effect of the association of sanitizers and surfactant in the microbiota of the Cantaloupe (Cucumis melo L.) melon surfaces. Food Control, v.16, p.369-373, 2005

6 BRANDL, M., AMUNDSON, R. Leaf age as a risk factor in the contamination of lettuce with Escherichia coli O157:H7 and Salmonella enterica. Applied and Environmental Microbiology, v. 74, p.2298-2306, 2008.

7 BUSSCHER, H.J., WEERKAMP, A.H., VAN DER MEI, H.C., VAN PELT, A.W., DE JONG, H.P., ARENDS, J. Measurement of the surface freeenergy of bacterial cell surface and its relevance for adhesion. Applied Environmental Microbiology, v. 48, p.980-83, 1984.

8 CAO, S., HU, Z., PANG, B., WANG, H., XIE, H., WU, F. Effect of ultrasound treatment on fruit decay and quality maintenance in strawberry after harvest. Food Control, v.21, n.4, p.529-532, 2010.

9 CASTRO, L.A.S.; SANHUEZA, R.M.V.; CANTILLANO, R.F.F.; ROCHA, N.E.M.

10 Metodologia para observação da camada de cera em maçãs utilizando microscopia eletrônica de varredura. Rev. Bras. Frutic., v. 24, n. 3, p. 774-775, 2002.

11 FORGHANI, F., OH, DEOG-HWAN. Hurdle enhancement of slightly acidic electrolyzed water antimicrobial efficacy on Chinese cabbage, lettuce, sesame leaf and spinach using ultrasonication and water wash. Food Microbiology, v.36, n.1, p.40-49, 2013.

12 GARRET,T. R., BHAKOO, M., ZHANG, Z. 2008, Bacterial adhesion and biofilms on surfaces. Progress in Natural Science, 18(9):1049-1056.

13 GOGATE, P.R., \& KABADI, A.M. A review of applications of cavitation in biochemical engineering/biotechnology. Biochemical Engineering Journal, v.44, n.1, p.60-72, 2009.

14 GOLMOHAMADI, A., MOLLER, G., POWERS, J., NINDO, C. Effect of ultrasound frequency on antioxidant activity, total phenolic and anthocyanin content of red raspberry puree. Ultrasonics Sonochemistry, v.20, n.5, p.1316-1323, 2013.

15 HUANG, Y.; CHEN, H. Effect of organic acids, hydrogen peroxide and mild heat on inactivation of Escherichia coli 0157:H7 on baby spinach. Food Control, v.22, n.8, p.1178-1183, 2011.

16 KATAINEN, J.,PAAJANEN, M., AHTOLAA, E., POREB, V., LAHTINEN, J. Adhesion as an interplay between particle size and surface roughness. Journal Colloids Interface Science, v.304, p.524-529, 2006.

17 KATSIKOGIANNI, M., MISSIRLIS, Y.F. Concise review of mechanisms of bacterial adhesion to biomaterials and of techniques used in estimating bacteria-material interactions. European Cells and Materials, v.8, p.37-57, 2004.

18 LIMA, P.M., SÃO JOSÉ, J.F.B., ANDRADE, N.J., PIRES, A.C.S., FERREIRA, S.O. Interaction between natural microbiota and physicochemical characteristics of lettuce surfaces can influence the attachment of Salmonella Enteritidis. Food Control, v.30, n.1, p.157-161, 2013.

19 MILLAN-SANGO, D.; McELHATTON, A.;VALDDRAMIDIS, V.P. Determination of the efficacy of ultrasound in combination with the essential oil oregano for the decontamination of Escherichia coli on inoculated lettuce leaves. Food Research International, v.67, p.145-154, 2015.

20 NASTOU, A., RHOADES, J., SMIRNIOTIS, P., MAKRI, I., KONTOMINAS, M., \& LIKOTRAFITI, E. Efficacy of household washing treatments for the control of Listeria monocytogenes on salad vegetables. International Journal of Food Microbiology, v.159, n.3, p.247-253, 2012.

21 PARISH, M. E., BEUCHAT, L. R., SUSLOW, T. V., HARRIS, L. J., GARRETT, E. H., FARBER, J. N., et al. Methods to reduce/eliminate pathogens from fresh and fresh-cut produce. Comprehensive Reviews in Food Science and Food Safety, v.2, p.161-173, 2003.

22 PIYASENA, P., MOHAREB, E., \& MCKELLAR, R.C. Inactivation of microbes using ultrasound: a review. International Journal of Food Microbiology, v.87, n.3, p.207-216, 2003.

23 RICO, D., MARTÍN-DIANA, A. B., BARAT, J. M., \& BARRY-RYAN, C. Extending and measuring the quality of fresh-cut fruit and vegetables: a review. Trends in Food Science and Technology, v.18, n.7, 373-386, 2007.

24 RUÍZ-CRUZ, S., ISLAS-OSUNA, M.A., SOTELLO-MUNDO, R., VÁZQUEZ-ORTEZ, F., GONZÁLEZ-AGUILAR, G.A. Sanitation procedure affects biochemical and nutritional changes of shredded carrots. Journal of Food Science, v.72, n.2, p.s146-s152, 2007.

25 SAGONG, H.G., LEE, S.-Y., CHANG, P.S., HEU, S., RYU, S., CHOI, Y.J., KANG, D.H. Combined effect of ultrasound and organic acids to reduce Escherichia coli $\mathrm{O} 157: \mathrm{H7}$, Salmonella Typhimurium, and Listeria monocytogenes on organic fresh lettuce. International Journal of Food Microbiology, v.145, n.1, p.287-292, 2011. 
SÃO JOSÉ, J.F.B., \& VANETTI, M.C.D. Effect of ultrasound and commercial sanitizers on natural microbiota and Salmonella enterica Typhimurium on cherry tomatoes. Food Control, v.24, n.1-2, p.95-99, 2012.

27 SÃO JOSÉ, J.F.B.; ANDRADE, N. J.; RAMOS, A. M.; VANETTI, M. C. D.; STRINGHETA, P. C.; CHAVES, J.B. P. Decontamination by ultrasound application in fresh fruits and vegetables. Food Control, v.45, n.1, p.36-50, 2014.

28 SELMA, M.V., IBANEZA, A. M., ALLENDE, A., CANTWELLA, M., \& SUSLOW, T. Effect of gaseous ozone and hot water on microbial and sensory quality of cantaloupe and potential transference of Escherichia coli $0157: \mathrm{H} 7$ during cutting. Food Microbiology, v.25, n. 1, p.162-168, 2008.

29 SENGÜN, I. Y., \& KARAPINAR, M. Effectiveness of lemon juice, vinegar and their mixture in the elimination of Salmonella Typhimurium on carrots (Daucus carota L.). International Journal of Food Microbiology, v.96, p.301-305, 2004.

30 SIVAPALASINGAM, S., FRIEDMAN, C. R., COHEN, L., AND TAUXE, R. V. Fresh produce: a growing cause of outbreaks of foodborne illness in the United States, 1973 through 1997. Journal of Food Protection, v. 67, p. 2342-2353, 2004.

31 UKUKU, D.O., FETT, W.F. Relationship of cell surface charge and hydrophobicity to strength of attachment of bacteria to cantaloupe rind. Journal of Food Protection, v.65, p.1093-1099, 2002.

32 VAN OSS, C.J., GIESE, R.F. The hidrophilicity and hidrophobicity of clay minerals. Clays and Clay Minerals, v.43, p.474-477,1995.

33 VOGLER, E. A. Structure and reactivity of water at biomaterial surfaces. Advances in colloid and interface science 74 , 69-117, 1998.

34 WANG, H., FENG, H., LIANG, W., LUO, Y., MALYARCHUK, V. 2009. Effect of surface roughness on retention and removal of Escherichia coli O157:H7on surfaces of Selected fruits. Journal of Food Science, v.74, n.1, e8-e15, 2009.

35 WANG, C., WANG, S., CHANG, T., SHI, L., YANG, H., SHAO, Y. Efficacy of lactic acid in reducing foodborne pathogens in minimally processed lotus sprouts. Food Control, v.30, p.721-726, 2013.

\section{ACKNOWLEDGEMENTS}

We thank Conselho Nacional de Desenvolvimento Científico e Tecnológico (CNPq/Brasil), Coordenação de Aperfeiçoamento de Pessoal de Nível Superior (CAPES/Brasil) for granting scholarships. We are grateful to Physics Department (UFV) for providing roughness measurements. 